\title{
The Impact of Muslim Religious Groups on the Changing Roles of Muslim Women in the Philippines: A Study of Tabligh Jama'ah, Markazosshabab, and Ahl al-Bayt
}

\author{
Ni'mah Ummu Hani Didaagun Barra
}

\begin{abstract}
This research analyses the impact of three religious groups, Tabligh Jama'ah, Markazosshabab fil Filibbin and Ahl al-Bayt in the Philippines on the changing roles of Muslim women. Of necessity, this research examines the coming of Islamic resurgence in the Philippines and the traditional to contemporary roles played by Filipino Muslim women. This study is based upon primary and secondary sources such as books, articles, journals, newspapers, government reports, non-governmental organization's reports, policy statements, and press releases. The researcher also carried out interviews with key figures of the three religious. The findings show the impact of these religious groups in terms of donning hijab and participating in Islamic religious assembly or activities not just at the local but also at the national level.
\end{abstract}

\section{Introduction Of The Study}

The role of Muslim women in the Islamic world provokes much discussion. The twentieth century witnessed an unprecedented Islamic resurgence that was felt in different parts of the world. It was a phenomenon that was expected to occur in response to the politico-economic and socio-cultural dominance, impositions, and influence of the West. Islamic resurgence took various forms such as: the extremist, the conservative, and the liberal or modernist. ${ }^{1}$ This includes the changes in women's position in Muslim society.

The history of the Philippines is divided into four phases: the Pre-Spanish period, the Spanish period, the American period and the years since independence. ${ }^{2}$ These periods also provide a convenient framework to consider for the changing roles and status of women in the archipelago.

The Muslims in the Philippines are often referred to as Moros. ${ }^{3}$ They are divided into thirteen ethnolinguistic groups. ${ }^{4}$

Undeniably, the Spaniards and then the American invaders can trace the changing roles of women among theMuslim Filipino women land through the colonization that was brought. For the Muslim-Filipinos, these two colonial powers had comparable missionary objectives. The Spaniards dreamed of making over the Muslim Filipino women into little brown Hispanised Christians as they had the majority of lowland Filipinos. ${ }^{5}$ While the Americans did not seek to teach the Muslim Filipino women with the teachings of Christian religion as such, but did wish to win them over to "civilized" ways - that is, civilized in terms of American values. ${ }^{6}$ But prior to the coming of the Americans, the Muslim Filipino women's roles were associated with the home-based workers and regarded as weak. Muslim Filipino women's educational learning and economic activities were primarily confined at home. And because of its isolation, Muslim Filipino women subculture area is rich in folklore and folk-life. ${ }^{7}$ This stage, according to Dr. Frank Lauback, an American missionary who lived in Lanao, reported that the Muslim Filipino women were in "Homeric Age" at 1930's to 1970's. 'It was this stage where they were made to learn and recite lengthily and skillfully their epic song called the darangen, ${ }^{9}$ learned how to read, write and memorize chapters from the Qur'an because by tradition, Islam entered the Philippines in 1380 A. D. with the arrival of the Arab missionary Sharif Makdon. ${ }^{10}$

The change resulting from the western contact came at the beginning of the $20^{\text {th }}$ century, from the first inception of the Americans occupation to the present. ${ }^{11}$ Extensive public works and improvements in

\footnotetext{
${ }^{1}$ Norma A. Maruhom and Fatima Pir T. Allian, "Religious Extremism and Its Impact: The Case of the Southern Philippines" in Muslim Women and the Challenge of Islamic Extremism, edited by Norani Othman (Malaysia: Sisters in Islam, 2005$), 134$.

${ }^{2}$ Leonard Davis, Revolutionary Struggles in the Philippines, (London: The Macmillan Press, 1989), 119.

${ }^{3}$ Referred as the Muslim-Filipinos.

${ }^{4}$ Norma Maruhom and Fatima Allian..., 135.

${ }^{5}$ Peter Gowing, Muslim Filipinos..., 38.

${ }^{6}$ Ibid.

${ }^{7}$ Mamitua Saber and Abdullah Madale, Magical and Curative Practice in The Muslim Filipino women Society, (Manila: Solidaridad Publishing house, 1975), 65.

${ }^{8}$ Mamitua Saber and Abdullah Madale..., 66

${ }^{9}$ Darangen is the traditional poetry of Muslim Filipino women

${ }^{10}$ Nagasura T. Madale, The Muslim Filipino, (Quezon City: Alemar-Phoenix Publishing House, Inc., 1981), 38.

${ }^{11}$ Mamitua Saber and Abdullah T. Madale,.., 25.
} 
communications were undertaken. ${ }^{12}$ The introduction of a system of formal education, the modification of socioeconomic and political Muslim Filipino women institutions, and the improved communication facilities initiated by the Americans have apparently contributed to the changing roles of the Muslim Filipino women in their society. ${ }^{13}$

Though improvements and new ideas have been embraced by many, this $20^{\text {th }}$ century also witnessed an unprecedented Islamic resurgence that was felt in different parts of the world. The Islamic resurgence in Southern Philippines, where Marawi City belongs, exists in the forms of movements and organizations. ${ }^{14}$ This research therefore focuses on the movements of three religious groups-TablighJama'ah, MarkazosshababfilFilibbin, and the Ahl al-Bayt-and their impacts on the changing roles of Muslim Filipino women today. Though Ahl al-Bayt religious group was believed by their followers that it came to Philippines since the beginning of Islamization in the Philippines. Yet the group has been rapidly increased this $20^{\text {th }}$ century.

Muslim Filipino women are born into a community that is emerging from social stratification with civil and religious functions, ${ }^{15}$ still some promote and emphasize only the conservative Islamic views of women based on the interpretations of the Qur'an developed by the classical jurists. ${ }^{16}$ Hence, lectures about Muslim women delivered by da'wah workers are often limited to their roles or identity as wives, social workers, community organizers, or income earners. ${ }^{17}$ Yet, today, Muslim Filipino women have become more active in performing their civic duties in the society. Though some religious Muslim Filipino womengroups strongly criticized these duties for they oppose the idea of frequent meetings of men and women, they still continued undertaking community activities within, for instance, Marawi City or in Zamboanga.

Our society is in transition and this is evident in our daily lives. Nevertheless, levels of awareness are rising. The changing roles of women are still issues that need to be answered especially to society that changes at its pace.

\section{Emergence Of The Religious Groups In The Philippines}

Since the twentieth century witnessed an unprecedented Islamic resurgence that was felt in different parts of the world. As a phenomenon expected to occur in response to the politico-economic and socio-cultural dominance, impositions, and influence of the West, Islamic resurgence took various forms and were labeled as the extremist, the conservative, and the liberal. ${ }^{18}$ One of the sufficient here to point out is the Bangsamorohomeland had been shrinking and the Muslims are becoming a minority in their own communities with a surging sense of Muslim identity, a fact that has generated the current crisis that now shakes the Philippine nation and this become the main causes of the social unrest in Mindanao. ${ }^{19}$

\section{The Islamic Resurgence as an International Movement}

The situation of Muslims in the Philippines became an issue of concern to the international Islamic community in the late 1960s, following the Jabidahmassacre and other human rights violations against Muslims. ${ }^{20}$ This Jabidah massacre is referred to the twenty Muslims from Tausug tribe who were killed in Corregidor Island in the Philippines. For this, many Muslims in the Philippines were appalled and incensed at this inhuman treatment of the Muslim trainees. ${ }^{21}$ This training of the twenty Tausugswere allegedly in preparation for a covert operation to take back the island of Sabah in Malaysia. However, this covert operation was aborted, yet giving the other Philippine soldiers to kill the twenty Tausug. That was also at the height of the trouble in Mindanao when martial law was proclaimed, and many young Muslims joined the ranks of the Moro National Liberation Front (MNLF). ${ }^{22}$ In this way, other foreign countries gave assistance and channeling arms into the Muslim in the Philippines, Particularly in Mindanao and Sulu. For example, Libya's President Qaddafi began to openly identify with the cause of Moro nationalism, supplying arms and financial aid to the MNLF and supporting its efforts to be recognized by the Islamic Conference of Foreign Ministers. ${ }^{23}$

Undeniably, the trend that we find among the Muslim communities in the Philippines was the establishment of mosques, Muslim religious schools or madaris(i.e. plural of madrasah) and other Islamic institutions. In order to safeguard their religion and its teachings, Muslim communities established Islamic

\footnotetext{
${ }^{12}$ P. Gowing, 36.

${ }^{13}$ AminaSumagayan, "The Changing Role of Maranao Women in a Maranao Rural Society”, Dansalan Quarterly, Vol IX No 4, (Gowing Memorial Research Center: Marawi City, July 1987), 165.

${ }^{14}$ N. Maruhom and F. Allian...,134.

${ }^{15}$ M. Saber and A. Madale..., 28.

${ }^{16}$ N. Maruhom and F. Allian..., 150.

${ }^{17}$ Ibid.

${ }^{18}$ Norma A. Maruhom 134.

${ }^{19}$ Hamid Barra, Code of Muslim Personal Laws: A Study of Islamic Law in the Philippines, (Mindanao: Padilla Press, 1988$), 2$.

${ }^{20}$ Jacques Siapno, Gender Relations and Islamic Resurgence in Mindanao, Southern Philippines, (Oxford: Berg Publisher, 1994), 189.

${ }^{21}$ P. Gowing, Muslim Filipinos..., 192

22 Ibid.

${ }^{23}$ J. Siapno, 189 .
} 
Arabic schools locally known as madrasah. The madrasah offers subjects in reading and writing in Arabic, Islamic law and jurisprudence, theology, reciting and learning the exergis of the Qur'an, Prophetic traditions, life history of the Prophet, and Islamic history. It was in 1950s when many among the new generation of ulama in Muslim Mindanao received their education in the Middle East like Al-Azhar University in Cairo, Egypt, renowned for its intellectual influence on the worldwide movement of Islamic reformism, Kuwait Universities, and Saudi Arabia in particular has provided scholarships for study in a number of Muslim countries, as well as economic support which has enabled the ulama in Mindanao to expand the existing and building of new madrasas (religious schools). ${ }^{24}$ In the early 1970s when many of the students in the Middle East began coming home after finishing their studies and were employed by Muslim institutions abroad as da'wah workers in their hometowns, as a result, there was the establishment of many madaris and an increase in their enrollment. ${ }^{25}$ Those who did not join the movement enrolled in the madaris so that they could help maintain their religion which was then, in the mind of the Muslims, under siege. ${ }^{26}$

Thus, in most cases, the mosques and the madrasah, were important learning centers. Through these mosques Islam was taught to the native Muslim-Filipinos in Mindanao. ${ }^{27}$ The mosques and the madrasah were basic institutions for Islamic education. ${ }^{28}$ Until now, Islamic education is present in the community of Muslim Filipino areas, but it is integrated with the western education. Through this also, the emergence of different religious groups have been organized by Muslim Filipinos.

Nevertheless, it is true that some people founded movements, whether in conservative or in liberal category, to use revolutionary tactics to promote their cause and some simply founded religious groups, which are the core of this study that tilted to more peaceful means in promoting their agenda, specifically through Islamic teachings that would be benefited by the community.

\section{Traditional And Contemporary Roles Of Filipino Muslim Women}

The purpose of this study is to bring into light the early position of women in Filipino Muslim society for us to have an idea how the changes happened over the years. In fairness to the significance of the Filipino Muslim women highly regarded role in the developing Filipino Muslimsociety, this study intends to correct the impressionists' adverse picture of the Filipino Muslim women as completely subservient to their men, and as giving little importance to their role in life-facts which have consequently assigned them to a secondary status in society. ${ }^{29}$

\section{A. Traditional Roles}

Prior to the coming of the conquerors to Philippine island, like the Americans, the women's educational and economic activities were primarily confined at home. Since their parents already embraced Islam, it was here where they were taught how to read, write, and memorize chapters from the HolyQur'an. They were made to learn Filipino Muslim songs known as bayok ${ }^{30}$ and phrases from the darangen ${ }^{31}$ as well as the art of playing the kulintang ${ }^{32}$, and making mat or weaving. ${ }^{33}$

The modern behavior of women like going out of the house and roaming outside the house without any companion was not accepted in the past and considered a wrongful act. This restraint on the women's leaving the home for an unnecessary purpose was a manifestation of the society's high regard and protection of the women's dignity and honor and the fear that "over-exposure" outside the house may bring about psychological social, and moral problems. ${ }^{34}$

The following activities were assumed by the Filipino Muslim women even before the colonization of the Philippines and during the Islamization of the Southern part of the Philippines. As for Sumagayan, this may further show the immemorial importance in Filipino Muslim society. ${ }^{35}$ This was also the time that some Muslim Filipino men, including the Filipino Muslims, were involved still in the process of organizing the Islamic resurgence in the region and convincing each Filipino Muslim men to join the undertakings. Thus, the following were some of the traditional roles played by the Filipino Muslim women:

\section{Home Obligations and Child Rearing}

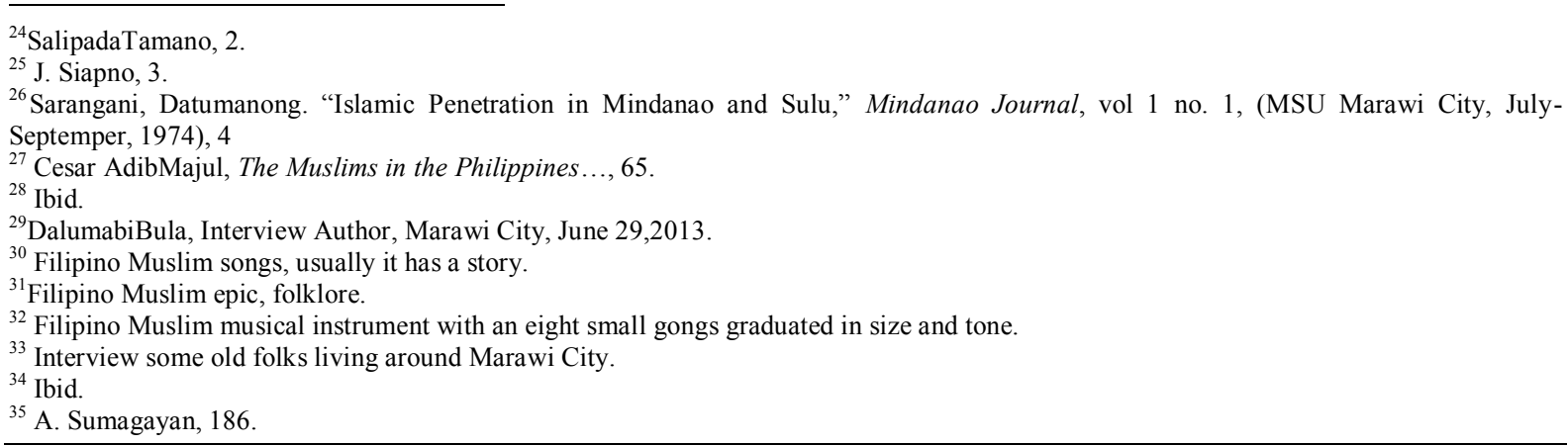


Islam has entrusted the obligations of the home to a woman, who is in charge of the household work and looks after the nourishing, education and training of the children. The Prophet is reported to have said, "Woman is the guardian of her husband's household and his children and she will be questioned concerning them." (Bukhari and Abu Dawud). ${ }^{36}$ Hence, this means that children must find their patience, care, love, and every possible advancement in their all-round education. ${ }^{37}$ The wife herself is responsible for the care of her home and the welfare of the family ${ }^{38}$ which includes the husband and children.

Women have played an important part in their homes, particularly in the training of their children. Management of the household and domestic chores has been the women's responsibilities. The daily routine includes: cooking, washing dishes and utensils, cleaning the house, fetching water from the river, serving food at home, gathering firewood, washing clothes, negotiating for foodstuffs with neighbors and entertaining visitors, mainly females.

For a man to do the above-mentioned activities are ridiculous, and he is laughed at by the barrio-folks, neighbors, except when his wife, for instance, is physically incapable to work due to illness or after giving birth, and there is no other woman living in the same household. Unmarried men, likewise, do no household work.

Taking care and rearing of children, such as feeding and putting them to sleep are all women's tasks. She teaches children proper behaviors, honesty and respect for parents, elders and other people. For example, as mentioned in the writing of Sumagayan, that the sense of respect, like calling persons older than oneself bapa (uncle) for older men, babo (aunt) for older women, and kaka (male or female older than one's self) is inculcated in the young not only by their parents, but by other women in the family. ${ }^{39}$

To the Filipino Muslims, according to the old ones, a misbehavior or misconduct of a child is judged by others as a reflection of his/her parents' personality. It is, therefore, the duty of every parent, especially mothers, to teach their daughters the value of good manners, refinement, and chastity, because a smear of her character would injure the reputation of her parents and lower the prestige of her family. To a married woman, the prestige and honor of her husband as well as her husband's relatives would be unfavorably affected if she misbehaves.

\section{Home Industry}

Clothe-weaving is a traditional activity generally done by women of all ages or status-married, unmarried and widows. What constitutes practically women's occupation is weaving blankets or bedding, langkit ${ }^{40}$ and malong ${ }^{41}$ and this is the best productiveness among Filipino Muslim women before.

According to the old folks that the researcher interviewed, some sewer's women are the one who produce fine hand-embroidered pillowcase, handkerchiefs, women's apparel, and decorative items designed with flowers, leaves and birds. Borrowing and copying one another's design is the practice. Women who own stores embroider while attending to their stores and using as much time as possible a way from their routine household duties. ${ }^{42}$

Like weaving, embroidery or sewing is an individual activity, and it is not an organized endeavor. Some embroidered articles, like handkerchiefs, are occasionally given free — as a gift with a person's name - to friends and relatives. Yet sometimes, their husband or father will go to the barter and will sell the embroidered stuff. Thus making this work as their way of earning money to buy foods and things that are necessary to their families.

\section{Way of Clothing}

Filipino Muslim's custome is malong where they can wear anywhere, formally or in an informal occasion. The malongis a tube-like, unisex garment that also symbolizes the Filipino Muslim's artform and culture. ${ }^{43}$ It is the most colorful unisex dress of the Filipino Muslim. In one sense, it is simply a barrel or pillowcase-formed skirt with equal circumferential opening on both ends, either of which is the entrance or exit for the wearer. ${ }^{44}$ Expressive of the rich artistic tradition of the people, it is also probably the most versatile apparel in the world. ${ }^{45}$ It can be blanket, towel, pillow-case, and so on. ${ }^{46}$

\footnotetext{
${ }^{36}$ AfzularRahman, Role of Muslim Woman in Society, (London: Seerah Foundation, 1986), 284.

${ }^{37}$ Lemu, 36 .

${ }^{38} \mathrm{Ibid}, 18$.

${ }^{39}$ A. Sumagayan, 190-191.

${ }^{40}$ Referred to a strip of cloth used for decoration and as an art piece used in joining the unsewn malong.

${ }^{41}$ Referred to Filipino Muslims (Filipino Muslim women, Tausug, Maguindanaon) traditional women dress; It is a tube-like, unisex garment that also symbolizes the Filipino Muslim's art form and culture.

${ }_{42}$ A. Sumagayan, 195.

${ }^{43}$ Christine, F. Godinez-Ortega, The Malong: Symbol of Filipino Muslim, Integrated Performing Arts Guild, (August 27, 2012)

http://m.facebook.com/note.php?note_id=427596443942936\&_ft_=fbid.427596443942936, accessed Sept 2, 2013 .

${ }^{44}$ MindameraMacarambon, Art Crafts and Uses of Malong, Mindanao Culture and Arts, Issue 2, (MSU: University Research Center, 1979), 31.

${ }^{45}$ Ibid.
} 


\section{Role in Choosing a Prospective Spouse}

In the past, a Filipino Muslim woman did not have the right to choose her husband. Completely, this early and arranged marriage is a Filipino Muslim tradition that was practiced by the parents or guardians to search and choose the right man or woman for their children. ${ }^{47}$ According to one of the women respondents, Mrs. SaphiaSulog who was from an arranged marriage and who got married at the age of 13 years old, parents arranged the unions among themselves and often without asking the ones who are to be married. Sometimes, the couples are not prepared emotionally and intellectually for this kind of responsibility that the marriages require, and yet this does not seem to matter to the parents or guardians. This is the reason why, for other respondents, few of these arranged marriages are unsuccessful.

Henceforth, these general traditional roles played by the Filipino Muslim women in the Filipino Muslim society have changed because of elements like modernization, in some ways the impact of the religious groups, for the Filipino Muslim women have been subjected to adopt these influences and changes.

\section{B. Contemporary Roles}

Based on the traditional roles of the Filipino Muslim women, there is a need to enumerate some of the contemporary roles they portray. However, the changes brought about by the three religious groups are discussed in the next chapter. The following are the most common contemporary roles played by the Filipino Muslim women in Marawi City.

\section{Women as an educator}

Islam secures women's rights in education and work. The Prophet responded positively and instantly to women asking him to allocate a certain time to teach them Islam regularly. ${ }^{48}$ Women should educate themselves so that they can contribute positively to the society through their intellect, talent, and ability. ${ }^{49} \mathrm{~A}$ complete educational system was introduced for barrio primary school to university, with U.S textbooks that oriented Filipinos toward a U.S. or Western way of life that seemed superior. ${ }^{50}$ This can be seen through the changes of the Filipino Muslim society's especially in the educational system in the whole Philippines.

The idea of formal education was brought to the Filipino Muslims in 1903 by the Americans. ${ }^{51}$ During the early American colonial period, the conservative attitude of the people toward education slowed down the process of extending education to everyone, including the female members of the Filipino Muslim community. In the early American campaign for formal education, Professor Bula says that parents kept the girls away from schools. Only few were persuaded to send their sons to school at the instance of the Americans. This was so because education was earlier associated with Christianity. Filipino Muslim people, specially those who are in a high rank, like sultans or from a Royal blood, suspected the Americans of using education as instrument to hasten the spread of Christianity. statement:

The early Muslims opposition to the impact of the Western education as further exemplified in this

"The Muslim resistance of the establishment of the schools in their aread resulted in their educational development being delayed by at least fifty years. Even when schools were finally established by the Americans, they had to resort to certain incentives and, often, even force to persuade the Muslim parents to send their children to school. In the Lanao areas, the Americans at first used forced through the Philippine Constabulary to ferret out Muslim children of school, age and have them go to school. It was not unusual for Muslim datus to hide their children in big wooden trunkcs whenever PC soldiers arrived. Instead, they sent their slaves to school, presenting them as their children. Later this policy was changed to one of attraction in which Muslim children were bribed with all kinds of gifts as well as scholarships to the normal schools in hopes of getting the Muslims trained as teachers. Thus, this last policy made hundreds of Muslim children finally went to school., 52

It took the Filipino Muslims a number of years to overcome their suspicions and doubts and thus, appreciate the value of education for their daughters. This awakening in some way enhanced progress within the Filipino Muslim society. An educated Filipino Muslim woman is no longer secluded within home. Girls now are

\footnotetext{
${ }^{46}$ Ibid.

${ }^{47}$ SaphiaSulog, Interview with the Author, MarinautMarawi City, August 3, 2013.

${ }^{48}$ F. Osman, 34.

${ }^{49}$ ShehzadSaleem, Islam and Women: Misconceptions and Misperceptions, (Lahore: Al-Mawrid,2010), 3.

${ }^{50}$ William J. Pomeroy, The Philippines: Colonialism, Collaboration, and Resistance, (New York: International Publisher, 1992$), 7$.

${ }^{51}$ Quoted in H.F. Funtecha, Fourth Annual Report of the Philippine Commission, Part II, American Military Occupation of the Lake Lanao Region, 1901-1913, (Marawi City: MSU Research Center, 1979), 63.

${ }^{52}$ NagamuraMadale, "The Philippines Educational System and the Muslim Child," The Muslim Filipinos, (MSU: University Research Center, 1979), 290.
} 
seeking education in public co-educational schools. ${ }^{53}$ Thus, the protective seclusion of women appears to be dying out. ${ }^{54}$

Being an educator, nowadays, women in Marawi city can choose their future spouse. Filipino Muslim women, even men, voiced out who they want to marry. Unlike their seclusion and restricted life in the past, women and men today may entertain suitors at home or outside of it. ${ }^{55}$ If the parents want someone, a consent from their daughter or son is a requirement.

\section{Women as Entrepreneurs}

The introduction of the new system of education and the opening of new employment, opportunities have allowed the Filipino Muslim women to assume new roles within their society. ${ }^{56}$

You can see the Filipino Muslim women now who are entrepreneurs or business women. They can be seen in any establishments like supermarkets and malls, within or outside Marawi City. Earning for themselves is certainly not prohibited. They can pursue careers just as men can. However, as pointed out, they should always give due respect to the precepts of the shari'ah. ${ }^{57}$ For instance, even in business places, being modest and wearing hijab is permissible for some Filipino Muslim. Specially, if the family is a member of religious groups.

\section{Women as Political Participative}

A vast majority of Muslim scholars believes that women cannot become heads of state.$^{58}$ Even some of the Ulama in the Philippines, particularly in Marawi City, believed that women should not be participative, for example, in socio-economic matters. Yet, nowadays, Filipino Muslim women have enjoyed greater participation in the affairs of the community, as compared with the women in the past. According to Ex-Vice Mayor of Marawi City, Honorable YasminAlaCalandada, women of today are not excluded from participating in national and local political campaigns. In every election, especially in the local elections, women play an important role in the house-to-house campaign where candidates and their sympathizers visit houses to win the family's votes. ${ }^{59}$ It is also worth mentioning that one of the three congressional candidates in Marawi is a woman, name Honorable FaisahDumarpa, and some of the Governmental Head of Political Institutions are also women. Thus, Filipino Muslim women, unexpectedly, have become active on politics.

\section{Women Clothing Today}

When it comes to the way of clothing, key informants said that the wearing of malong, in and outside of the house, is not anymore visible among women, specially among the young ones. Filipino Muslim women today are wearing hijab, abaya, or even niqab. The donning of hijab become compulsory to schools and universities in Marawi City ${ }^{60}$ that even Christian students in high school institutions do wear. Undeniably, some Muslims in the Philippines, allow any dress that fulfills the required modesty for a Filipino Muslim woman. This shows the new trend that is brought by the Western dress. For example, the elegant combinations of colors on lace dresses, blouses, jeans, or coat that made stylish and covered the 'aurat'. Hence, Filipino Muslims everywhere in the Philippines tried to combine a Muslim-Westernized fashion in their hijab.

\section{Women as Organizers of Community Activities}

Educated Filipino Muslim women have become more active in performing their civic duties by organizing community activities for old, young, professional, and illiterate ones. ${ }^{61}$ Like the Almujadilah Foundation Development, ${ }^{62}$ where it is a non-profit women organization that advocates gender justice, peace building, governance and human rights. Mostly, all the Muslim women organizations, according to Zahra Mapandi, are both governmental and non-governmental, show their solidarity and oneness in adherence to Islamic ideology of having a strong and united Ummah.

As women become community organizers, and since there are different religious groups, the women members from the said different religious groups also organize activities to promote their ideologies. For instance, the Akhawat members of the Markazosshababorganized a yearly Muslim Women Assembly that is being participated by women only. Just recently, Akhawat organized their 30th Muslim World Assembly,

\footnotetext{
${ }^{53}$ A. Sumagayan, 205

${ }^{54}$ Ibid.

${ }^{55}$ A. Sumagayan, 211.

${ }^{56}$ BIR Head, HedjarahSulogBotawan, BIR Office, BanggoloMarawi City, Interview Author, June 13, 2013.

${ }^{57}$ ShehzadSaleem, Islam and Women: Misconceptions and Misperceptions, (Lahore: Al-Mawrid,2010), 3.

${ }^{58}$ Shehzad Salem, 11.

${ }^{59}$ Hon. YasminAlaCalandada, Interview Author, Marawi City, July 1, 2013.

${ }^{60}$ Principal BaeMambuay, Interview Author, Mambuay Elementary School, Marawi City, June 18, 2013.

${ }^{61}$ Zahra Mapandi, Interview Author, AMDF Office, Marawi City, June 14, 2013.

${ }^{62}$ A non-govermental Muslim women organization.
} 
entitled: "LangowanaMinitayao a DatunaPangongorianan o Bilantadi a Bae" (Behind Every Great Man, There is a Great Woman), June 22-23, 2013, MarantaoMarawi City.

Similar to the MasturaJama'ah of TablīghiJama'ah who also organized ta'alim everyday at different locations in Marawi City, and involved themselves on the Tablighiijtima or assembly in different location in and outside the Marawi City.

Lastly, the Followers of HazratZaynab (as) of Ahl al-Bayt organized Islamic seminars, but usually only the members are invited to the event.

The transformation of Muslim women roles in contemporary Muslim societies, for some contradicts the teachings of Islam, and has a negative impact on it. It is a fact that cannot be denied. However, there is always another positive fact that exists side by side within the society to fulfill their Islamic responsibilities and is increasingly appreciated among Muslim men and women.

We can observe here that there is a strong, unified, self-reliant, and God-fearing Muslim women who played their roles in the Filipino Muslim society. Even they are being influenced by some Western way of life, specifically on the educational system. They still maintain the value of family and their faith. Indeed, there is a mutual understanding and cooperation between the religious groups and women that helped outline the responsibilities of each, and influenced the roles of women not just in the family members but also as part of the society.

\section{a. Features of the religious groups' impact ${ }^{63}$ \\ IV. Impact Of The Religious Groups}

Basically, for the respondents, the religious groups have influenced the roles of Meranao women in society. Hence, this is presented in table 4.1:

Table 4.1

\begin{tabular}{|l|l|l|}
\hline \multicolumn{1}{|c|}{ The impact of the religious groups can be seen through: } & Frequency & Percentage \\
\hline 1. Muslim women become more religious; & 103 & $23 \%$ \\
\hline 2. Muslim women are now more keen on attaining education; & 112 & $25 \%$ \\
\hline 3. Muslim women are more keen on professional occupation; & 85 & $19 \%$ \\
\hline 4. Muslim women are participative to the civic duties on the society; & 101 & $22 \%$ \\
\hline 5. Muslimwomen are engaged now in an economic stability of the society; & 34 & $8 \%$ \\
\hline 6. I don't know & 15 & $3 \%$ \\
\hline \multicolumn{1}{|c|}{ Total } & 450 & $100 \%$ \\
\hline
\end{tabular}

Norma Maruhom also expounds that that Muslim Filipino women today are visibly more active than before in socio-economic, religious and political roles. Moreover, the impact of the religious groups can be seen through attaining education. Muslim women are more keen on attaining education nowadays with $25 \%$ out of the total population. For them, education is a stepping-stone to be part of the outside sphere of their home. Their education and work in different fields have developed their personality, self-confidence and initiatives. An awareness of their Islamic rights and responsibilities has inspired many of them to be committed to the Islamic message of justice, peace, and prosperity. These concrete developments have provided a support for Muslim woman, stronger than any philosophical or legal arguments. ${ }^{64}$

\section{Impact of the three religious groups among the secular-oriented women}

Thus, majority of the sample population strongly agreed that the secular-oriented Filipino Muslim women were impacted by the three religious groups teachings.

Secular oriented people accept that there is an impact of the three religious groups on their changing roles. Firstly, this was indicated on the donning hijab everywhere, attending some Islamic halaqah/multaqah or women seminars organized by the three religious groups; and learning or adopting some ideas based on principles or ideologies of each religious groups.

To start with the donning of hijab, it has ultimately become part of every Filipino Muslim women fashion today. Since some of the Ulama from these three religious groups came from the Middle East universities, they attempted to adopt Islamic lifestyles from them, i.e., Saudi Arabia, Pakistan, and Iran.

Thus, this is a trend found among the Muslims in the Southern part of the Philippines. This is manifested in the manner of dressing of Muslims (both men and women) that are patterned on the Middle Eastern, South and Southeast Asian styles. Graduates from the Middle Eastern Islamic universities are sometimes seen in the clothing style of their alma mater. Members of the TablighiJama'ah are easily identified by Pakistani or Indian type of dressing. Those who graduated or visited Southeast Asian countries are keen to use the styles in their countries. Muslim women in the Philippines, nowadays, wear colorful headdresses of some Southeast Asian and Middle Eastern variety (like combong, tudung, or hijab,) all styled in various

\footnotetext{
${ }^{63}$ In doing this study, the researcher had distributed 450 questionnaires to the different areas of Muslim Filipinos, men and women, in the Philippines. The respondents were from the three religious groups and from individuals that were not members of the said groups.

${ }^{64}$ Aisha Lemu and Fatima Heeren..., 36.
} 
manners. There are, however, those who, except for their eyes, cover their faces with black hijab matched with long-sleeved loose-black long dress or abaya. Most of those who observe this kind of dress code are members of the MasturahJama'ah (the women members of the TablighJama'ah) or the Akhawat (the women members of the Markazosshabab) and even those of the Ahl al-Bayt women members.

\section{Conclusion and Analysis of the Impact of the Religious Groups on the Changing Roles of Filipino Muslim Women}

Through the findings of this research, the impact of the three religious groups can be seen into Filipino Muslimsociety, specially on Filipino Muslim women - whether secular-oriented or not, and lastly, on the Islamic awareness of few Filipinos — at national level—on the issue of Muslim women in Islam.

\section{Impact on Filipino Muslim Society and Filipino Muslim Women}

The impact of the religious groups on the changing roles of Filipino Muslim women can be seen in the following factors. These factors are based on the features that are given in the respondents' answers about their view on the impact of the religious groups on women, but in a more emphasized approach. Definitely, the secular-oriented women also noticeably perceived these impacts. This focuses on the establishments of different religious assembly organized by the religious groups, donning the hijab, concept on integration of Islamic and Western education, and active participants in community activities.

\section{a. Establishments of different religious assemblies by the religious groups}

An evident sign of the impact of the three religious groups is the increase in the number of people interested in disseminating the pristine truth of Islam. In Marawi City alone, different religious groups were organizing different Islamic seminars everyday, once a week, or once a month for women. ${ }^{65}$ This seminars or assembly were usually for the Filipino Muslim women who wanted to be enlightened on the message of the Holy Qur'an, Sunnah and Hadith, or even on the issue of marriage, etc. At times, they organized gatherings for those who want to learn and read the Qur'an properly, even the secular-oriented people were enticed to join. ${ }^{66}$

\section{b. Through the noticeable trend towards donning the hijab}

As mentioned in previous pages, a number of Muslim women subscribed to what the ulamaperceive to be part of the Islamic mode of dressing. For example, donning of hijab has ultimately become part of every Filipino Muslimwomen fashion today. Since some of the Ulama from these three religious groups came from the Middle East universities, they adopted Islamic lifestyles from there (i.e., Saudi Arabia, Pakistan, and Iran). There is no local ordinance or law that forces women to wear hijab or to follow any particular dress code. However, in the madaris and in some offices and/or in secular schools, the wearing of hijab is required or made mandatory as part of the employees' and student uniforms.

This shows that women members of the Tablīgh, Markazosshabab, and Ahl al-Bayt were also required to wear the hijab. Often, they were seen with their faces covered, except their eyes, with matching long-sleeved, loose black long dresses. To some Muslim women, or the secularists, colorful donning hijab was part of their fashion, but to a few of them it was also political statement, a symbol of asserting one's identity as a Muslim, and to be organized and respected in a society dominated by non-Muslims ${ }^{67}$

As discussed above in the previous tables, donning hijab was the primary impact of the religious groups. Most Muslim women today wear a full-face veil. Yet it is more common to see women in hijab, loose clothing topped by a type of scarf worn around the head and under the chin. Women do not share a common style, nor do they have the reasons for wearing hijab.

Today, with the trend to revive or create Islamic movements, women have continued to take up the modest covering of the hijab. Norma Maruhom explains that if one wishes to pursue professional or in public social lives, wearing hijab allows freer movement outside the limits of the home. In the same way, students who take up hijab are able to move into areas that were once barred to them, such as attending classes, discussion groups and religious activities.

\section{c. The concept of Islamic and Western Education}

Beginning in 1973, there was an increase in the number of Islamic/Arabic schools or madaris. This increase was made possible by the growth in the number of pupils enrolling in the madrasah and the return to the Philippines of graduates from the Middle-East universities who were paid as missionary teachers by concerned Islamic organizations and agencies in the Muslim world. ${ }^{68}$ The increase in the number of madaris led

\footnotetext{
${ }^{65}$ Based on the interviews of the key informants.

${ }^{66}$ Ibid.

${ }^{67}$ N. Maruhom, 141.

${ }^{68}$ H. Barra, 14.
} 
to the organization of seminars, adult classes and Qur'anic study groups. Even the old folks now at Marawi City are active in learning to read the Qur'an. This is also manifested through the integration of Islamic institutions. For example, Markazosshababschools, like Ibn Siena Integrated School's ${ }^{69}$ education are based on the integration of Islamic and Western system of education. This has been imitated by some old and new institutes or schools in Marawi City. ${ }^{70}$

\section{d. Active participants in community activities}

In all the roles that women play in the society, the impacts of religious groups are noticeable. Additionally, they are considered having encouraging signs of women visibly becoming active participants in the community activities. This can be seen through the different non-profit organizations established within Marawi City. As mentioned in the previous chapter, even members of each of the religious groups have organized female groups for them to focus on issues of women. Undeniably, this changing women's roles are present in Filipino Muslim society. These days we meet Filipino Muslim women as educators, politicians, businesswomen, or preachers.

\section{Bibliography}

[1]. Barra, Hamid D. (1988). Code of Muslim Personal Laws: A Study of Islamic Law in the Philippines. Mindanao: Padilla Press.

[2]. Chan Robles Virtual Law Library, "Treaty of General Relations Between the Republic of the Philippines and the United States of America, July 4, 1946, Manila”, <http://www.chanrobles.com/rpustreatyofgeneralrelations.htm (accessed 21 December 2013).

[3]. Davis, Leonard. (1989). Revolutionary Struggles in the Philippines. London: Macmillan Press.

[4]. Edwards, Louise and Roces, Mina. (2000). (eds). Women in Asia: tradition, modernity, and globalization. Australia: Allen and Unwin.

[5]. George, T. J. S. (1980).Revolt in Mindanao: The Rise of Islam in Philippine Politics. Kuala Lumpur: Oxford University Press.

[6]. Gowing, Peter G. (1979). Muslim Filipinos and their Homeland: Heritage and Horizon. Quezon City: New day Publisher

[7]. Gowing, Peter G.. (1977). Mandate in Moroland: The American Government of Muslim Filipios 1899-1920. Quezon City: Community Publishers Inc,.

[8]. Heyzer, Noeleen. (1986). Working Women In South-East Asia: Development, subordination, and emancipation. England: Open University Press.

[9]. Isidro, Antonio and Saber, Mamitua. (1968). (eds). Muslim Philippines. Marawi City: Mindanao State University Research Center.

[10]. Jubair, Salah. (1999). Bangsamoro: A Nation Under Endless Tyranny. Kuala Lumpur: IQ Marin SDN BHD.

[11]. Madale, Nagasura T. (1981) ed. The Muslim Filipinos: A Book of Readings. Quezon City: Alemar-Phonex Publishing House, Inc.

[12]. Majul, Cesar Adib. (1973). Muslims in the Philippines ( $2^{\text {nd }}$ edn.). Quezon City University of the Philippines Press.

[13]. Majul, Cesar Adib. (1974). The Muslims in the Philippines: An Historical perspective in Gowing, P.G. and McAmis, R.D. (eds.), The Muslims Filipinos: Their history, society and contemporary problems (pp. 1-12). Manila: Solidaridad Publishing House.

[14]. Majul, Cesar Adib. (1974). In Succession in the Old Sulu Sultanate: A Historical perspective in Gowing, P.G. and McAmis, R.D. (eds). The Muslims Filipinos: Their history, society and contemporary problems (pp 61-73). Manila: Solidaridad Publishing House.

[15]. MaulanaWahibuddin Khan. (2000). Woman Between Islam and Western Society. Delhi: Nice Printing Press.

[16]. Muslim, Macapado. (1994). The Moro Armed Struggle in the Philippines: The Nonviolent Autonomy Alternative. Mindanao State University: University Press and Information Office.

[17]. Othman Norani. (2005). (ed). Muslim Women and the Challenge of Islamic Extremism. Kuala Lumpur: Sisters in Islam.

[18]. Panda, Ali. (1989). Formation of the Ulama Political Party: The Case of the Ompia Party in Lanao del Sur. Masteral Thesis, U.P. Diliman: Quezon City.

[19]. Rahman, Afzular. (1986). Role of Muslim Women in Society. London: Seerah Foundation

[20]. Saleem, Shehzad. (2010). Islam and Women: Misconceptions and Misperceptions. Lahore: Al-Mawrid.

[21]. Siapno, Jacques. (1994). Gender Relations and Islamic Resurgence in Mindanao, Southern Philippines. Oxford: Berg Publisher.

[22]. Siddiqi, Mazheruddin. (2004). Women in Islam. New Delhi: Adam Publishers and Distributions.

[23]. Tamano, Salipada. (1974). Historical Background of Madaris in the Philippines.Marawi City: Mindanao State University Press.

[24]. Tjomsland, Marit\& Karin Ask, (ed). (1998). Women and Islamization: Contemporary Dimensions of Discourse on Gender Relations. New York: Berg Publisher.

[25]. W. K. Che Man. (1990) Muslim Separatism: The Moros of Southern Philippines and the Malays of Southern Thailand. Singapore: Oxford University Press.

[26]. Yousif, Ahmad F. ed. (2012).Muslim Revivalism. Canada: Gauvin Press

\section{Other Document}

[27]. Al-Mujadilah Development Foundation, Inc. (2008). R.A 9262: Anti-Violence Against Women and their Children Act. Asia Foundation and SentrongAlternatibongLingapPanligal. No. 30394-26-330-26-18005.

[28]. Markazosshabab Al-Muslim Fil-Filibin. (July 10, 2009). Knowing Markazosshabab: Markazosshabab 30 ${ }^{\text {th }}$ Anniversary. Marawi City: Markazosshabab Handouts.

\section{Journal}

[29]. Ahmad, Syed Neaz. (2008, May). Dialogue: The way forward. The Muslim world league journal, 36(5).

[30]. Alilayah, Alfaro I. "The Muslims in the Philippines: Their History and the Martial Arts", Mindanao Islamic Journal: Toward Islamization of Knowledge, Vol. 4 No. 1, January-December 1992, 79. Kings Faisal Center for Islamic, Arabic and Asia Studies, MSU.

\footnotetext{
${ }^{69}$ Markazosshabab's first and experimental school for elementary and secondary school.

${ }^{70}$ Based on the interviews and observation of the researcher. Numerous new school has been following this Western and Islamic integration when it comes to education. Some of the new schools are Al-Khawarizmi International School, Aba al-Khayr Integrated School, Philippines International School, and Al-Farabi School.
} 
[31]. Macasalong, Marjanie Salic. "Mindanao Conflict and Islamic Revivalism: The Moro Islamic Liberation Front's Approach", Islam and Civilizational Renewal, Volume 4, Number 2, April 2013, 253.

[32]. Mindanao Islamic Journals: Towards Islamization of Knowledge. King Faisal for Islamic and Arabic Studies: Marawi City. Vol 3 No. 1 (January-December 1991).

[33]. Mindanao Islamic Journal: Towards Islamization of Knowledge: King Faizal for Islamic and Arabic Studies: Marawi City. Vol.XIX No. 1-2 (July-December 1992).

[34]. Sarangani, Datumanong. (1974). "Islamic Penetration in Mindanao and Sulu," Mindanao Journal, vol 1 no. 1, MSU Marawi City, July-Septemper.

[35]. Sumagayan, Aminah P.U. (July 1987). The Changing Roles of Meranao Women in a Meranao Rural Society. Dansalan Quarterly, issue $0115-866 \mathrm{X}$.

\section{Online Newspaper}

[36]. Domini M. Torrevilas, "Muslim Women Want their Voices Heard", The Philippine Star, February 19 , 2013. http://www.philstar.com/opinion/2013/02/19/910495/muslim-women-want-their-voices-heard accessed October 22, 2013.

[37]. Lillian Goldman Law Library, "A treaty of Peace between the United States and Spain", $<$ http://avalon.law.yale.edu/19th_century/sp1898.asp> accessed December 21, 2013.

\section{Dissertation}

[38]. Bangcola, Hedjarah. (2011). Jama'ahTablīgh in Marawi City: Legality and Da'wah.Unpublished masteral dissertation. Mindanao State University, Marawi City.

[39]. Macasalong, Marjanie Salic. (2013). "The Liberation Movements in Mindanao: Root Causes and Prospects for Peace”. Unpublished masteral dissertation. ISTAC, International Islamic University Malaysia, Kuala Lumpur.

[40]. Moh'dQassem, Nadhera. (2010). Performance of the Ummah party in the Philippines elections in Lanao del Sur province.Unpublished masteral dissertation.International Islamic University Malaysia, Kuala Lumpur. 